\title{
Trait Analysis of the Dentition of the Torahumara Indians and Mestizos of the Sierra Madre Occidental, Mexico *
}

\author{
RICHARD G. SNYDER, ${ }^{1}$ ALBERT A. DAHLBERG, ${ }^{2}$ CLYDE C. SNOW ${ }^{3}$ \\ AND THELMA DAHLBERG ${ }^{2}$ \\ ${ }^{1}$ Department of Anthropology, The University of Michigan, Ann Arbor; \\ ${ }^{2}$ Department of Anthropology and Zoller Memorial Dental Clinic, \\ University of Chicago, Illinois; and ${ }^{3}$ Civil Aeromedical Institute, \\ Federal Aviation Administration, Oklahoma City, Oklahoma
}

\begin{abstract}
A new approach of trait analysis of the dentition is presented, based upon study of both deciduous and permanent dentitions of 114 Tarahumara Indians and 63 Mestizos of both sexes and ranging in age from 5 to 23 years. Molar cusp patterns and numbers, and odontometrics were analyzed and compared, and penetrance, sexual dimorphism, and concordance were investigated.

To examine penetrance and expressivity of Carabelli's cusp and the protostylid, five categories of description of the surface upon which these cusps normally appear were made. Of particular importance was the finding that when expressivity of these traits is examined based upon a trait analysis scale which includes the entire range of expressions of the trait the frequency may be much higher than generally believed. Carabelli's cusp ranged from $95 \%$ for Mestizo males to $100 \%$ for Tarahumara males, although low frequency has been previously considered a Mongoloid trait. Current work is underway to re-examine several previous American Indian dental collections utilizing this technique of more discrete trait analysis.
\end{abstract}

In recent years, physical anthropologists have devoted much effort to the study of morphological and physiological traits that are discretely expressed and, usually, under fairly simple genetic control. The blood groups, hemoglobins and PTC taste sensitivity are examples of such traits which have proved invaluable in the comparison of racial groups throughout the world. In most cases, these features are expressed in an "all or none" manner and their mechanisms of inheritance are known well enough that the frequencies of their controlling genes within a population can be calculated with considerable precision. In contrast, most dental traits, such as the protostylid and Carabelli's cusp, appear to be polygenic and, moreover, their degree of expression is further influenced by, as yet, ill-understood factors controlling penetrance. Complicating matters further is the lack of real knowledge of the genetic mechanisms governing their absence, presence and degree of expression since, unlike the blood groups, few family histories and pedigrees are yet available from which modes of inheritance can be derived. A final difficulty arises from the lack of uni- formity in the description of these traits and, in particular, the failure of many workers to recognize and report the lowpenetrance manifestations of a particular trait. On the other hand, inherited dental features offer the advantage of preservation in fossil materials so that both living and dead populations can be compared in terms of phenotypic frequencies and, ultimately, as their underlying genetic bases become better understood, it should be possible to describe genotypes and gene frequencies of prehistoric populations. Meanwhile, it is important that the methods of analysis and classification of the phenotypic expressions of the several dental traits currently under study be uniform so that populations may be directly compared. In the present paper, based on the study of the dentitions of the Tarahumara Indians of Northwestern Mexico and their Mestizo neighbors, the authors present a new approach to the problem as it applies to the quantitative description of the incidence and degree of expression of the protostylid and the cusp of Carabelli.

* This work was supported in part by PHS grant no. 1874 of the National Institute of Dental Research. 


\section{The Tarahumara}

Despite the intensive study of aboriginal cultures of North America there still remain some tribes that have received only a cursory glance from the physical anthropologist. One such group is the Tarahumara, a Uto-Aztecan speaking people numbering some 50,000 individuals who inhabit the rugged Sierra Madre Occidental of southwestern Chihuahua and northern Sinaloa. Forbidding geography and climate, coupled with their own inclination to shun contact with outsiders, have combined to preserve in Tarahumara culture many features that typified prehistoric cultures of the American Southwest and Northern Mexico.

The area in which they live is about 300 by $500 \mathrm{~km}$ in extent and straddles the north-central segment of the Sierra Madre Occidental embracing the watershed and tributaries of two large rivers-the Rio Concho which drains the eastern aspect and the Rio Fuerte which flows to the Gulf of California.

The available archaeological evidence indicates that the Tarahumara have lived in their present habitat for a considerable period of time-perhaps as long as 2,000 years (Pennington, '63; Zingg, '40; Ascher and Clune, '60; and Gajdusek, '53). Physiographically, the area may be divided into two regions: uplands and canyon country (Pennington, '63). The uplands are pineand pasture-clad plateaus with elevations of 1,200 to $2,400 \mathrm{~m}$ and occasional peaks measuring $3,000 \mathrm{~m}$. The canyon country is formed by the Rio Fuerte drainage system and consists of gigantic gorges, the barrancas, which may attain depths of 800 to $1,800 \mathrm{~m}$ and whose floors support a subtropical biota.

The summer climate of the barrancas is torrid and unhealthy, while that of the uplands is relatively cool and pleasant. In the winter, on the other hand, the climate of the uplands is the coldest in Mexico while the canyons offer warmth and shelter. Rainfall is scanty on both areas and tends to be concentrated in late summer and early fall.

The Tarahumara, whose rude technology equips him poorly for either upland winters or barranca summers (Zingg, '42), has responded to this environmental challenge by developing a seminomadic living pattern. In the spring, many families move to the highlands where they plant, tend and harvest their crops. In the fall, they retreat to the canyons where they spend the winter in comparative comfort.

As mentioned above, many features of Tarahumara culture must be very similar to those of pre-Columbian agriculturists of this general area. This observation is especially valid in regard to their diet, which consists largely of Indian corn stone ground and variously processed to prepare such foods as esquiate, atole, tortillas, and pinole. The latter, produced from ground parched corn which is then mixed with water to form a nourishing gruel, is the principal dietary item and, according to Bennett and Zingg ('35), forms well over $50 \%$ of the typical Tarahumara diet. The results of our own investigations indicate that corn preparations of one form or another account for about $65 \%$ of the total caloric intake; other domesticated plants, particularly bean and squash, form about $20 \%$ and wild plant foods about $10 \%$. Not more than about $5 \%$ of the diet is derived from animal sources. This low intake of animal foods comprised a wide variety of wild game and fish including deer, gopher, rats and mice, coati, badgers, otter, peccary and even skunks, hummingbirds, tadpoles and rattlesnakes. It is hardly an exaggeration to say that any wild thing in the Sierra that walks, flies, swims or crawls is a likely candidate for the Tarahumara stewpot. Although the Tarahumara have kept sheep and cattle since their introduction by the Spanish in the seventeenth century, these animals are rarely slaughtered for food and are not important dietary items. For a more detailed description of Tarahumara food economy, the reader is referred to the excellent monograph by Pennington ('63). In summary, the Tarahumara diet is based on the primitive corn-bean-squash triad supplemented by the intensive exploitation of wild plant and animal resources and, as such, in both manner of preparation and content, is probably very similar to that of preColumbian agriculturists throughout much of Mexico and the American Southwest. From this standpoint, the Tarahumara 
offer the anthropologist a unique opportunity to validate his observations on longdead populations of this region. For example, the degree of tooth wear, used by some workers to help develop estimates of the age structure of Southwestern skeletal populations could be at least partially confirmed by studies of wear among presentday Tarahumara.

Sharing the region with the Tarahumara is a population of mixed-bloods, or Mestizos, many of whom are the descendants of Spanish settlers who entered the Sierra as early as the sixteenth century. Racially, the Mestizo is difficult to define and, often in rural Mexico the distinction is drawn more along cultural and linguistic than biological lines: families of predominately Indian ancestry consider themselves, and are considered by their neighbors, to be Mestizo if they speak Spanish, participate in the Spanish-derived social, political and religious affairs of the community and think of themselves as "villagers" rather than "tribesmen," (Balke and Snow, '65). However, while the Mestizo of the Sierra usually displays his obviously Indian heritage, at the same time, his somewhat lighter pigmentation, tendency towards wavy or curly hair and more aquiline facial features generally serve to distinguish him phenotypically from the Tarahumara. Although the demographic and racial history of this region is still to be written, it is apparent that the Mestizo is, for the most part, the product of SpanishIndian racial blendings which occurred before his migration into the area and that little gene flow has occurred between the Mestizo and Tarahumara populations. The rarity of legitimatized matings between the Mestizo and Tarahumara is remarkable and attested by the fact that several priests, all long-term and well-acquainted residents of the area, could recall no more than six or eight cases of TarahumaraMestizo marriages. Although no statistics exist, irregular unions are also uncommon and the sanctions against them reinforced by the strongly-held (and often correct) Tarahumara belief that sexual intercourse with non-Tarahumara inevitably results in the development of a venereal infection by the Tarahumara partner. Thus the dentitions that we are comparing in the present study may be considered to represent two distinct breeding populations sharing the same physical environment. One, the Tarahumara, is both culturally and biologically a representative of the earlier pre-conquest populations of the greater Southwest. The other, the Mestizo, is the product of Spanish and Indian admixture which occurred, for the most part, elsewhere in Mexico and probably within a few generations after the Conquest.

\section{MATERIAL AND METHODS}

This report is based upon the study of the dentitions of 114 Tarahumara and 63 Mestizo of both sexes, ranging from 5 to 23 years of age. Mestizo refers to individuals one or both of whose parents are described as "white," "Spanish", or "Mestizo." Dental impressions and other measurements of these subjects were made at the Jesuit Mission of Sisoguichi, Chihuahua. Exceptions consisted of the members of a family showing some unique hereditary patterns and anomalies who live some 40 miles distant. Sisoguichi is located 300 air miles southwest of El Paso, Texas in a valley at $2,270 \mathrm{~m}$ altitude.

Impressions were made with Coe Alginate elastic impression powder and casts poured with white albastone. Temperature was not rigidly controlled due to the good field conditions. If additional examination or impressions were desired a child could be quickly located and all cooperated well due to the assistance of the priests and nuns. A careful record was kept of the subject's name, relationships, age, and whether Tarahumara or Mestizo. These were cross-checked with Mission records. A lower and upper impression was taken and, in some cases, full-face and profile photographs.

\section{DISCUSSION AND RESULTS}

Comparison of the mandibular occlusal surfaces demonstrates both a consistent difference between Tarahumara and Mestizo cuspal patterns and a decrease in cusp numbers from $\mathrm{dm}_{2}$ through $\mathrm{m}_{2}$ (fig. 1). Both male and female Mestizos show more reduced patterns for each mandibular molar group than do the Tarahumara. This might be expected due to the more recent racial admixture of the Mestizos. All de- 


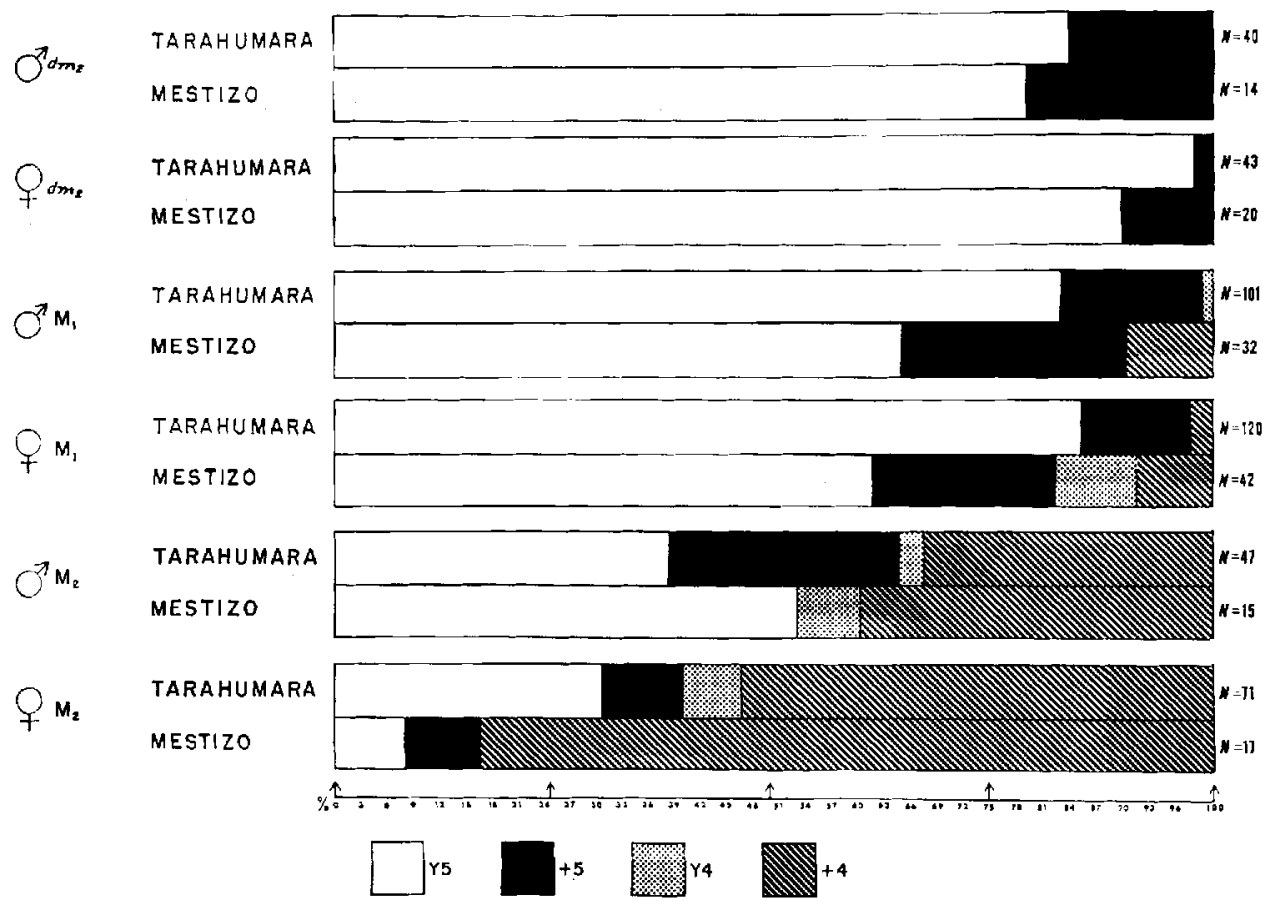

Fig. 1 Mandibular molar cusp patterns for Tarahumara and Mestizo children.

ciduous second molar teeth for both groups were found to have five cusps with from $80 \%$ (Mestizo males) to $98 \%$ (Tarahumara females) $\mathrm{Y}^{5}$ pattern. $\mathrm{Y}^{5}$ patterns were also more frequent for the first permanent molar teeth, ranging from $63 \%$ (Mestizo females) to $85 \%$ (Mestizo males); with only 1 to $9 \%$ either Y4 or +4 patterns. A striking sexual dimorphism is apparent for the second permanent molar teeth. Both Tarahumara and Mestizo females show more advanced cuspal patterns and fewer cusps than do the males. While, as with the other mandibular molars, the Mestizos show more reduced patterns than the Tarahumara, the females of both groups have a much greater frequency of Y4 and +4 patterns than do the males. Although no Y4 teeth were found for the Mestizo female first permanent molar teeth, $83 \%$ were +4 patterns (compared to $38 \%+4$ pattern in the Mestizo male). Thus, the second permanent mandibular molar tooth appears much more available than the second deciduous molar or the first permanent molar for these two groups.

The maxillary molar patterns are shown in figure 2. All deciduous second molar teeth for both groups were 4-cusped, being either 4 or 4 -. The first permanent molars were predominately (88-100\%) 4-patterns, including all of 31 Mestizo male children. However, there appeared to be more variability both in cuspal numbers and patterns, between Tarahumara and Mestizo children than was shown in the mandibular teeth. Note that the Tarahumara for both sexes show slightly more reduced patterns than the Mestizo, contrary to what was found in the mandibular teeth. A trend toward fewer cusps occurs in the second maxillary molar tooth, however, while Mestizo males show a much higher incidence of 3-cusped patterns than the Tarahumara males, the Mestizo females were observed to have some $12 \%$ more 4-cusped teeth in this group. Thus the maxillary molar teeth, and especially the second molar, show greater variability than do the mandibular molars.

Odontometrics are presented in figures $3-6$. The ordinate provides the scale to the closest millimeter as measured with a Boley gage. Each population is indicated as Tarahumara or Mestizo, male or female with the number, mean, and standard error 


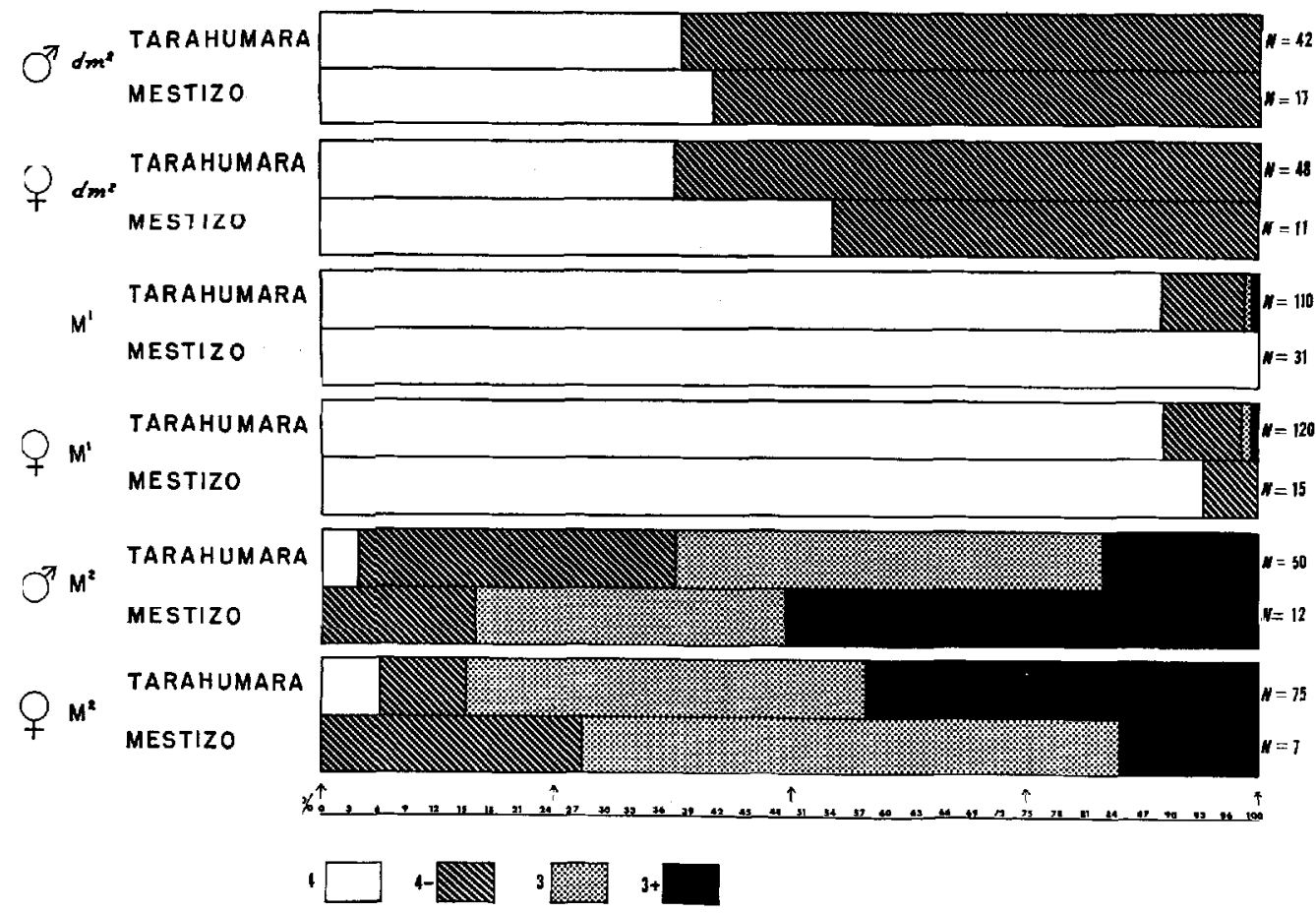

H'ig. `2 Maxillary molar cusp patterns for Tarahumara and Mestizo children.

of the mean indicated for each subgroup. Sample size varies due to the fewer subjects in certain early age categories. Thus, while there were 102 female Tarahumara mandibular permanent first molars examined, there were only ten male Mestizo deciduous mandibular first molars available. Measurements were independently checked by two of the authors.

Tarahumara males had a mean mandibular buccolingual crown diameter larger than the females or the Mestizo male and females for all four molar teeth studied (fig. 3). Mestizo males had larger mandibular buccolingual crown diameters than Mestizo females except for $\mathrm{dm}^{1}$. Tarahumara females had greater buccolingual crown diameters than Mestizo females except for $\mathrm{dm}^{1}$.

Mandibular mesiodistal crown diameter was largest for Tarahumara males for $\mathrm{dm}^{2}$ and $\mathrm{M}^{2}$, the same as for Tarahumara females, but exceeding both Mestizo males and females, for $\mathbf{M}^{1}$ (fig. 4). However, for $\mathrm{dm}^{1}$ Tarahumara males were exceeded in crown diameter by both the Tarahumara and Mestizo females. Mesiodistal crown diameter for $\mathrm{dm}^{1}$ was found to be larger in the females than males of both groups. The Tarahumara males had larger maxillary buccolingual crown diameters than the female for $\mathrm{dm}^{2}, \mathrm{M}^{1}$, and $\mathrm{M}^{2}$. The Mestizo and Tarahumara males had larger buccolingual diameters than the females for both $\mathrm{M}^{1}$ and $\mathrm{M}^{2}$ (fig. 5 ).

Maxillary crown diameter (mesio-distal) was larger for males than females for all four molar groups, and particularly so for the first permanent molar teeth (fig. 6). The most diagnostic tooth for sexual differentiation was the first permanent molar tooth, as mean buccolingual and mesiodistal measurements of the males exceeded the females for both maxillary and mandibular teeth, with the single exception of the mandibular M-D crown diameter.

The precise measurements for the molar crown diameters are tabulated in table 1. Each figure provides the mean value for combined left and right teeth. These measurements are similar with other 

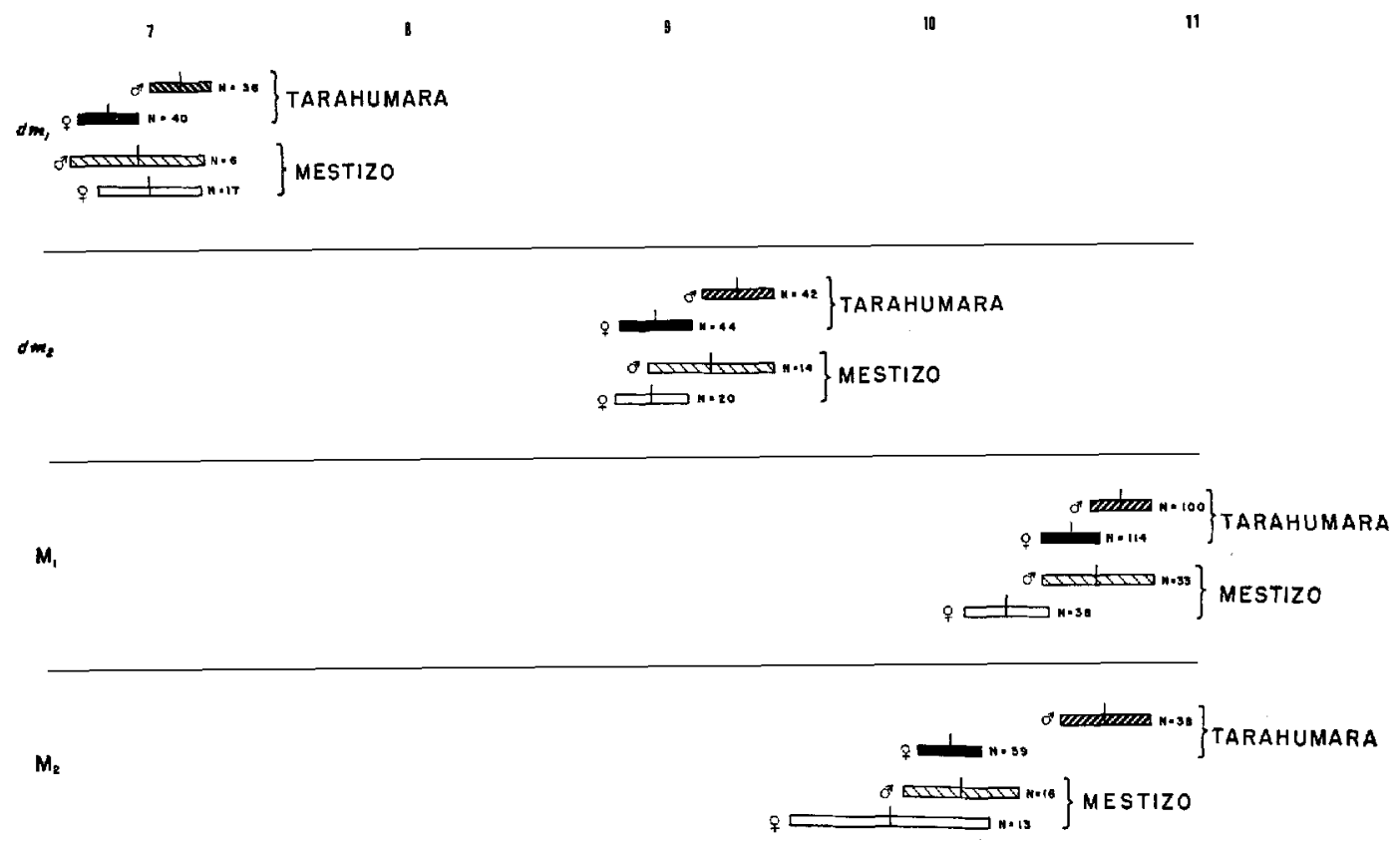

Fig. 3 Mandibular molar buccolingual crown diameters ( $\mathrm{mm}$ ) for Tarahumara and Mestizo children.

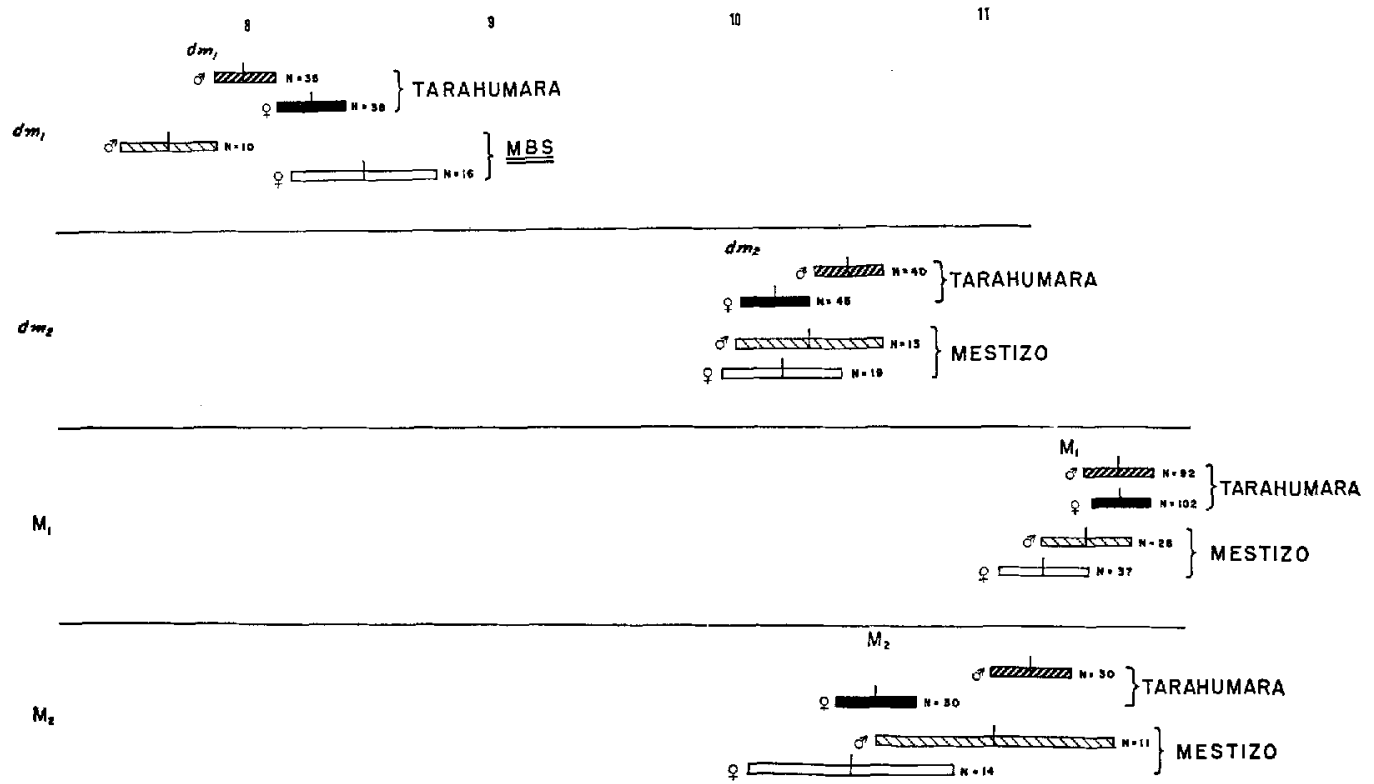

Fig. 4 Mandibular molar mesiodistal crown diameter $(\mathrm{mm})$ for Tarahumara and Mestizo children.

southwestern Indians and demonstrate no unusual variability (Dahlberg, '59). For example, while the mean Mestizo fermale mandibular buccolingual crown diameter of the second molar was found to be only $9.86 \mathrm{~mm}$, Hrdlicka ('23) noted the mean for Pueblo females as $9.67 \mathrm{~mm}$. However, as pointed out above, there were some sta- 


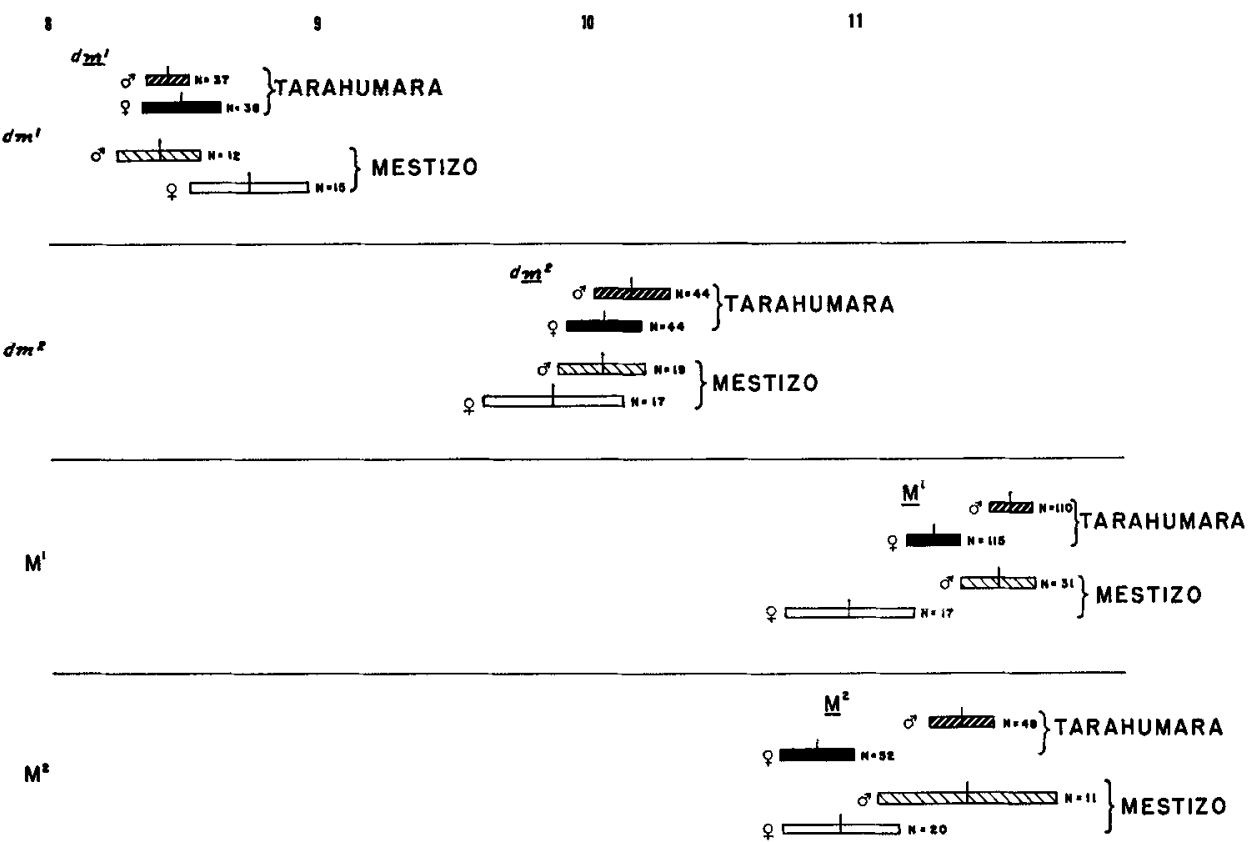

Fig. 5 Maxillary molar buccolingual crown diameters for Tarahumara and Mestizo children.
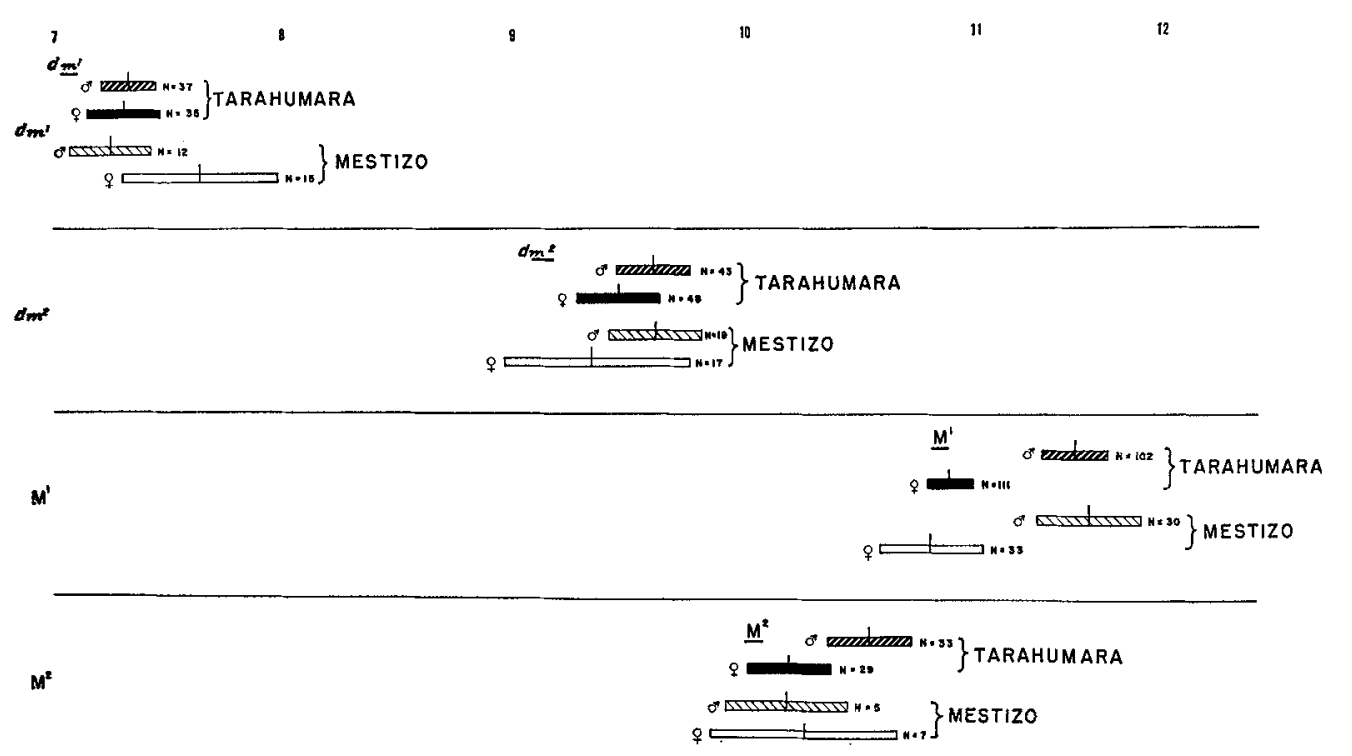

Fig. 6 Maxillary molar mesiodistal crown diameters ( $\mathrm{mm}$ ) for Tarahumara and Mestizo children.

tistically significant intra-group and sexual odontometrics.

Carabelli's cusp (von Carabelli, 1842) is an accessory cusp which generally occurs bilaterally on the anterior mesial aspect of the lingual surface of the maxillary permanent and deciduous molars. The protostylid (Dahlberg, '49) refers to a particular cusp 
TABLE 1

Crown diameters of deciduous and permanent molar teeth

\begin{tabular}{|c|c|c|c|c|c|c|c|c|c|}
\hline & & \multicolumn{2}{|c|}{$\mathrm{dm}_{1}$} & \multicolumn{2}{|c|}{$\mathrm{dm} \mathrm{m}_{2}$} & \multicolumn{2}{|c|}{$\mathbf{M}_{\mathbf{1}}$} & \multicolumn{2}{|c|}{$\mathbf{M}_{2}$} \\
\hline & & $\mathbf{B L}$ & MD & BL & MD & BL & MD & BL & MD \\
\hline $\begin{array}{l}\text { Tarahumara } \\
\text { female }\end{array}$ & $\begin{array}{l}\text { Maxillary } \\
\text { Mandibular }\end{array}$ & $\begin{array}{l}8.48 \\
6.84\end{array}$ & $\begin{array}{l}7.31 \\
8.26\end{array}$ & $\begin{array}{r}10.10 \\
8.95\end{array}$ & $\begin{array}{r}9.49 \\
10.16\end{array}$ & $\begin{array}{l}11.29 \\
10.55\end{array}$ & $\begin{array}{l}10.89 \\
11.60\end{array}$ & $\begin{array}{l}10.84 \\
10.08\end{array}$ & $\begin{array}{l}10.19 \\
10.56\end{array}$ \\
\hline $\begin{array}{l}\text { Tarahumara } \\
\text { male }\end{array}$ & $\begin{array}{l}\text { Maxillary } \\
\text { Mandibular }\end{array}$ & $\begin{array}{l}8.44 \\
7.12\end{array}$ & $\begin{array}{l}7.33 \\
7.98\end{array}$ & $\begin{array}{r}10.16 \\
9.27\end{array}$ & $\begin{array}{r}9.60 \\
10.46\end{array}$ & $\begin{array}{l}11.58 \\
10.73\end{array}$ & $\begin{array}{l}11.39 \\
11.54\end{array}$ & $\begin{array}{l}11.39 \\
10.69\end{array}$ & $\begin{array}{l}10.54 \\
11.20\end{array}$ \\
\hline $\begin{array}{l}\text { Mestizo } \\
\text { female }\end{array}$ & $\begin{array}{l}\text { Maxillary } \\
\text { Mandibular }\end{array}$ & $\begin{array}{l}8.74 \\
6.99\end{array}$ & $\begin{array}{l}7.64 \\
8.47\end{array}$ & $\begin{array}{l}9.87 \\
8.94\end{array}$ & $\begin{array}{r}9.37 \\
10.19\end{array}$ & $\begin{array}{l}10.97 \\
10.30\end{array}$ & $\begin{array}{l}10.82 \\
11.05\end{array}$ & $\begin{array}{r}10.93 \\
9.86\end{array}$ & $\begin{array}{l}10.26 \\
10.47\end{array}$ \\
\hline $\begin{array}{c}\text { Mestizo } \\
\text { male }\end{array}$ & $\begin{array}{l}\text { Maxillary } \\
\text { Mandibular }\end{array}$ & $\begin{array}{l}8.41 \\
6.95\end{array}$ & $\begin{array}{l}7.25 \\
7.67\end{array}$ & $\begin{array}{r}10.05 \\
9.17\end{array}$ & $\begin{array}{r}9.62 \\
10.30\end{array}$ & $\begin{array}{l}11.53 \\
10.65\end{array}$ & $\begin{array}{l}11.48 \\
11.42\end{array}$ & $\begin{array}{l}11.41 \\
10.13\end{array}$ & $\begin{array}{l}10.28 \\
11.05\end{array}$ \\
\hline
\end{tabular}

Mean values for right and left teeth combined.

which is found only upon the anterior portion of the buccal surfaces of lower molar teeth. It has a close relationship to the buccal groove separating the hypoconid from the protoconid.

Dietz ("44) defined four main categories for Carabelli's cusp: "lobular," "ridged," "cuspoid," and "pitted." Kraus ('51, '59) suggested the terms "pronounced tubercle" and "slight tubercle" in place of Dietz's "cuspoid" and "lobular" respectively. Jorgensen ('56) devised a three term classification "furrow" (for the fissure or groove found on the lingual surface of the protocone), "welt" (when the mesial half of furrow is more pronounced than the distal), and "pit" (for the small depression on the lingual protocone). Many other authors have found it convenient to use a three category description "cusp," "pit" and "groove," for Carabelli's anomaly and the protostylid. In many studies there may be some question as to whether all of the categories recognized as expressions of the anomaly have been noted, while on other classifications they have not been specified.

In the present study, an effort was made to cast light on the penetrance and expressivity of Carabelli's cusp and the protostylid. Careful attention was given to markings on the surface upon which these cusps normally occur. It was suspected that lack of penetrance or subclinical structures sometimes occurred. The Carabelli cusp classification used here consisted of a completely smooth surface (0), a surface having a pit or furrow interrupting its continuity $(f),{ }^{4}$ and three size grades of cusps ranging from an eminence without a defining groove $\left(c^{1}\right)$, a small cusp with a groove setting it off from the tooth surface $\left(c^{2}\right)$, to a large cusp $\left(c^{3}\right)$. These provide five categories of description of the area usable as degrees of expressivity for the feature in studies of concordance, sexual dimorphism and intergroup comparisons.

The dental casts were carefully examined in the laboratory and graded in accordance with degree of expression using the scale defined above. As shown by table 2 , the frequency of occurrence of Carabelli's cusp within individuals of the sample ranged from $95 \%$ for Mestizo males to $100 \%$ for Tarahumara males.

Analysis of the degree of expression was accomplished by dividing the sample into sub-groups according to side, sex, and race. Each degree of expression was then tallied for each tooth and a frequency distribution made. Each degree of expression was assigned a weight along a five point scale, with $0=0, f=1, C^{1}=2, C^{2}=3, C^{3}=4$. The frequency with which a particular degree of expression occurs within a particular sub-group was then multiplied by its appropriate weight. The products of this operation are summed and the total divided by the number of teeth examined in that particular sub-group. The result is an index reflecting the relative degree of expression typical of that class of tooth.

4 A furrow located at the site of the Carabelli's cusp on the mesial aspect of the lingual surface is to be distinguished from the groove which courses mesiolingually over the mesial marginal ridge of the occlusal surface and on to the mesial surface. 
TABLE 2

Carabelli's cusp. Frequencies, degree of expression, and $\chi^{2}$

\begin{tabular}{|c|c|c|c|c|c|c|c|c|c|c|c|c|}
\hline \multirow{2}{*}{ Tooth } & \multirow{2}{*}{ Race } & \multirow{2}{*}{ Sex } & \multirow{2}{*}{ Side } & \multirow{2}{*}{$\mathbf{N}$} & \multicolumn{5}{|c|}{ Expression } & \multicolumn{3}{|c|}{ Significance } \\
\hline & & & & & $\overline{\mathbf{o}}$ & $\mathbf{f}$ & $\mathrm{c}_{1}$ & $\mathrm{C}_{2}$ & $\overrightarrow{\mathrm{C}_{3}}$ & $\chi^{2}$ side & $\chi^{2} \operatorname{sex}$ & $\begin{array}{l}\text { Index of } \\
\text { expression }\end{array}$ \\
\hline \multirow{5}{*}{$\mathrm{dm}^{2}$} & \multirow{3}{*}{ Tarahumara } & $0^{\pi}$ & $\begin{array}{l}\mathbf{R} \\
\mathbf{L}\end{array}$ & $\begin{array}{l}15 \\
18\end{array}$ & $\begin{array}{l}0 \\
0\end{array}$ & $\begin{array}{l}5 \\
7\end{array}$ & $\begin{array}{l}9 \\
9\end{array}$ & $\begin{array}{l}1 \\
3\end{array}$ & $\begin{array}{l}0 \\
0\end{array}$ & n.s. & \multirow{3}{*}{0.05} & 1.76 \\
\hline & & & & & & & & & & & & \\
\hline & & $q$ & $\begin{array}{l}\mathbf{R} \\
\mathbf{L}\end{array}$ & $\begin{array}{l}19 \\
15\end{array}$ & $\begin{array}{l}0 \\
1\end{array}$ & $\begin{array}{l}16 \\
10\end{array}$ & $\begin{array}{l}3 \\
3\end{array}$ & $\begin{array}{l}0 \\
1\end{array}$ & $\begin{array}{l}0 \\
0\end{array}$ & n.s. & & 1.21 \\
\hline & \multirow[b]{2}{*}{ Mestizo } & $\sigma^{\circ}$ & $\begin{array}{l}\mathbf{R} \\
\mathbf{L}\end{array}$ & $\begin{array}{l}11 \\
12\end{array}$ & $\begin{array}{l}0 \\
0\end{array}$ & $\begin{array}{l}4 \\
4\end{array}$ & $\begin{array}{l}5 \\
6\end{array}$ & $\begin{array}{l}2 \\
2\end{array}$ & $\begin{array}{l}0 \\
0\end{array}$ & n.s. & \multirow[b]{2}{*}{ n.s. } & 1.83 \\
\hline & & $q$ & $\begin{array}{l}\mathbf{R} \\
\mathbf{L}\end{array}$ & $\begin{array}{l}14 \\
15\end{array}$ & $\begin{array}{l}0 \\
0\end{array}$ & $\begin{array}{l}3 \\
5\end{array}$ & $\begin{array}{l}11 \\
10\end{array}$ & $\begin{array}{l}0 \\
0\end{array}$ & $\begin{array}{l}0 \\
0\end{array}$ & n.s. & & 1.72 \\
\hline \multirow{5}{*}{$M^{1}$} & \multirow{3}{*}{ Tarahumara } & $\sigma^{*}$ & $\begin{array}{l}\mathrm{R} \\
\mathbf{L}\end{array}$ & $\begin{array}{l}50 \\
49\end{array}$ & $\begin{array}{l}0 \\
1\end{array}$ & $\begin{array}{l}11 \\
12\end{array}$ & $\begin{array}{l}28 \\
26\end{array}$ & $\begin{array}{r}10 \\
9\end{array}$ & $\begin{array}{l}1 \\
1\end{array}$ & n.s. & \multirow{3}{*}{0.005} & 1.98 \\
\hline & & & & & & & & & & & & \\
\hline & & 우 & $\begin{array}{l}\mathbf{R} \\
\mathbf{L}\end{array}$ & $\begin{array}{l}33 \\
33\end{array}$ & $\begin{array}{l}1 \\
1\end{array}$ & $\begin{array}{l}16 \\
17\end{array}$ & $\begin{array}{l}15 \\
14\end{array}$ & $\begin{array}{l}1 \\
1\end{array}$ & $\begin{array}{l}0 \\
0\end{array}$ & n.s. & & 1.47 \\
\hline & \multirow{2}{*}{ Mestizo } & $\sigma^{x}$ & $\begin{array}{l}\mathbf{R} \\
\mathbf{L}\end{array}$ & $\begin{array}{l}17 \\
19\end{array}$ & $\begin{array}{l}1 \\
1\end{array}$ & $\begin{array}{l}5 \\
4\end{array}$ & $\begin{array}{r}8 \\
10\end{array}$ & $\begin{array}{l}2 \\
4\end{array}$ & $\begin{array}{l}1 \\
0\end{array}$ & n.s. & \multirow{2}{*}{ n.s. } & 1.86 \\
\hline & & q & $\begin{array}{l}\mathbf{R} \\
\mathrm{L}\end{array}$ & $\begin{array}{l}39 \\
40\end{array}$ & $\begin{array}{l}2 \\
2\end{array}$ & $\begin{array}{l}13 \\
15\end{array}$ & $\begin{array}{l}18 \\
16\end{array}$ & $\begin{array}{l}5 \\
6\end{array}$ & $\begin{array}{l}1 \\
1\end{array}$ & n.s. & & 1.68 \\
\hline \multirow{4}{*}{$\mathrm{M}^{2}$} & \multirow[b]{2}{*}{ Tarahumara } & $a$ & $\begin{array}{l}\mathrm{R} \\
\mathrm{L}\end{array}$ & $\begin{array}{l}28 \\
28\end{array}$ & $\begin{array}{l}4 \\
2\end{array}$ & $\begin{array}{l}22 \\
25\end{array}$ & $\begin{array}{l}2 \\
0\end{array}$ & $\begin{array}{l}0 \\
1\end{array}$ & $\begin{array}{l}0 \\
0\end{array}$ & n.s. & \multirow[b]{2}{*}{ n.s. } & 0.96 \\
\hline & & q & $\begin{array}{l}\mathbf{R} \\
\mathbf{L}\end{array}$ & $\begin{array}{l}20 \\
22\end{array}$ & $\begin{array}{l}3 \\
8\end{array}$ & $\begin{array}{l}17 \\
13\end{array}$ & $\begin{array}{l}0 \\
1\end{array}$ & $\begin{array}{l}0 \\
0\end{array}$ & $\begin{array}{l}0 \\
0\end{array}$ & n.s. & & 0.76 \\
\hline & \multirow[b]{2}{*}{ Mestizo } & $\sigma^{*}$ & $\begin{array}{l}\mathbf{R} \\
\mathbf{L}\end{array}$ & $\begin{array}{l}7 \\
7\end{array}$ & $\begin{array}{l}3 \\
5\end{array}$ & $\begin{array}{l}4 \\
2\end{array}$ & $\begin{array}{l}0 \\
0\end{array}$ & $\begin{array}{l}0 \\
0\end{array}$ & $\begin{array}{l}0 \\
0\end{array}$ & n.s. & \multirow[b]{2}{*}{ n.s. } & 0.43 \\
\hline & & $q$ & $\begin{array}{l}\mathbf{R} \\
\mathbf{L}\end{array}$ & $\begin{array}{l}20 \\
21\end{array}$ & $\begin{array}{r}5 \\
11\end{array}$ & $\begin{array}{l}11 \\
10\end{array}$ & $\begin{array}{l}4 \\
0\end{array}$ & $\begin{array}{l}0 \\
0\end{array}$ & $\begin{array}{l}0 \\
0\end{array}$ & n.s. & & 0.71 \\
\hline
\end{tabular}

The following example demonstrates the calculation of this index for the right deciduous molar of Tarahumara males:

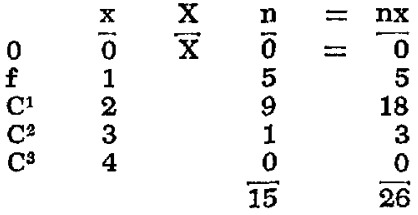

$$
\begin{aligned}
& 26 / 15=1.73 \text { index }
\end{aligned}
$$

The values found for other tooth classes (combined) are listed in figure 7. To determine whether any statistically significant differences occurred Chi-square tests were computed on right versus left sides for each tooth, using the raw frequency distribution. No cases were found in which side frequencies were significantly different for tooth groups showing the trait. Accordingly, both sides were combined for each tooth and the index of expression of Carabelli's cusp was computed for the combined side frequency using the factors of sex, race, and tooth. This is shown in figure 7. For Carabelli's cusp no significant difference was found between sexes in Mestizo for the second deciduous molar $\left(\mathrm{dm}^{2}\right)$, first $\left(\mathrm{M}^{1}\right)$, or second $\left(\mathrm{M}^{2}\right)$ permanent molar tooth, nor for the Tarahumara second molar $\left(\mathrm{M}^{2}\right)$. (It should be noted that the sample size of the latter group was rather small.) However, for the Tarahumara, sexual dimorphism for Carabelli's trait between males and females for the 


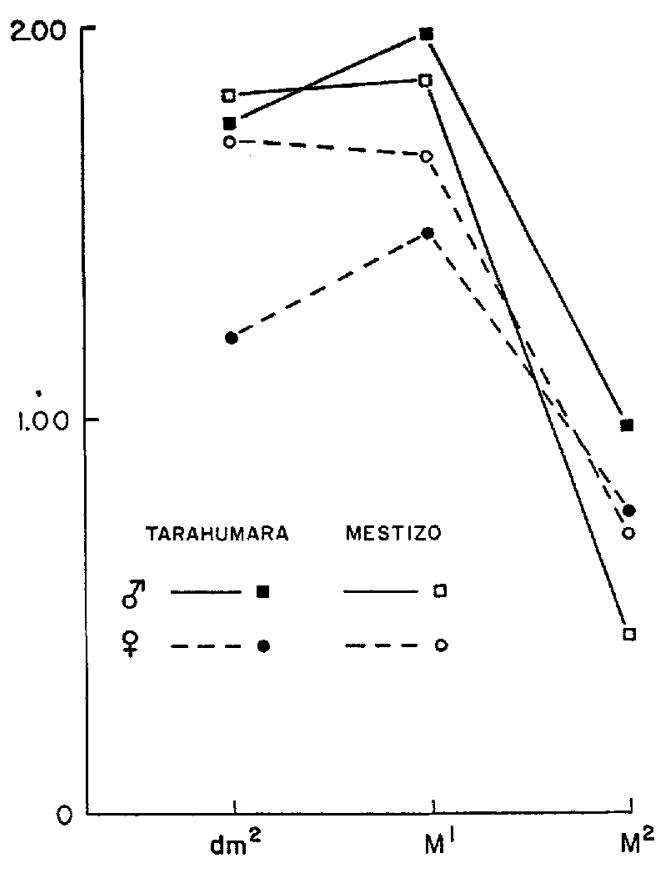

Fig. 7 Index showing relative degree of expression of Carabelli's cusp.

second deciduous molar $\left(\mathrm{dm}^{2}\right)$ was significant at the 0.05 probability level, and for the first permanent molar tooth at the 0.005 probability level.

A low frequency of Carabelli's cusp has generally been regarded as a diagnostic racial trait for Mongoloid populations (Dahlberg, '49). Incidence has indeed been reported as low for all American Indian groups in the literature, although Kraus ('59) found that unmixed Mongoloid populations show a low frequency of absence of the trait, as well as the maximum penetrance, but a very high frequency of intermediate penetrance. The very high incidence of Carabelli's cusp in this Tarahumara population may also be explained by the careful observance and recording of incidence of all gradations of the trait. Hence, the total frequencies of the alleles for the cusps are shown to be really much higher than they would be in considering the cusps on the traditional basis of recording and reporting.

Similar results were obtained in the case of the protostylid. For the purpose of description and comparison the protostylid was also viewed in five classes or degrees of expressivity, ranging from a completely uninterrupted surface $(0)$, a pit, a vertical wrinkle or undefined irregularity in continuity of the area (W), ${ }^{5}$ and eminence of cuspal design without a delineating groove outline $\left(\mathrm{P}^{1}\right)$, a small but positive elevation running mesio-occlusally from the gingival end of the buccal groove $\left(\mathrm{P}^{2}\right)$, to a well defined cusp of larger dimension $\left(\mathrm{P}^{3}\right)$.

The indices of expression of the protostylid trait were computed in the same manner as for Carabelli's cusp. Chi-square tests for right and left sides and sexes for each tooth group (e.g. second deciduous molar, first and second permanent molar) demonstrated no statistically significant differences (table 3 ), thus sides and sexes were lumped as shown in figure 8 . As can readily be seen, this results in a very clearcut straight-line increase in expression of the protostylid from $\mathrm{M}^{2}$ to $\mathrm{dm}^{2}$ for both Tarahumara and Mestizo children. While the Tarahumara show slightly greater degree of expression in $\mathrm{M}^{2}$ than the Mestizo, the Mestizo demonstrate greater expression in $\mathrm{M}$, and much greater expression in $\mathrm{dm}^{2}$.

\section{CONCLUSIONS}

The Tarahumara Indians of southwestern Chihuahua, Mexico, were found to possess a wide range of expression of several traits which serve well to demonstrate a new approach of trait analysis of the dentition. Dental casts were obtained and studied from 114 Tarahumara and 63 Mestizo of both sexes, aged 5 to 23 years, which allowed study of both deciduous and permanent dentitions. Molar cusp patterns and numbers, and odontometrics were analyzed of Carabelli's cusp and protostylid. Penetrance, sexual dimorphism, and concordance were investigated.

Comparison of mandibular occlusal surfaces showed a relative decrease in cusp numbers from the second deciduous molar through the second permanent molar, with Mestizos showing more reduced patterns for each tooth group. The maxillary molars, however, show greater variability for each group. The male mean buccolingual and mesiodistal crown diameters of the first permanent molar exceeded the female for both maxillary and mandibular teeth

\footnotetext{
Irregularities of surface contour in the protostylid site area are known to represent incomplete pene. trance of the protostylid.
} 
TABLE 3

Protostylid. Frequencies, degree of expression and $\chi^{2}$

\begin{tabular}{|c|c|c|c|c|c|c|c|c|c|c|c|c|c|}
\hline \multirow[b]{2}{*}{ Tooth } & \multirow[b]{2}{*}{ Race } & \multirow[b]{2}{*}{ Sex } & \multirow[b]{2}{*}{ Side } & \multirow[b]{2}{*}{$\mathbf{N}$} & \multicolumn{5}{|c|}{ Expression } & \multicolumn{4}{|c|}{ Test of significance } \\
\hline & & & & & 0 & $\begin{array}{c}\text { Furrow } \\
\text { Pit } \\
\end{array}$ & ${ }^{N-} \mathbf{P}_{1}$ & $\mathbf{P}_{2}$ & $P_{3}$ & $\chi^{2}$ side & $x^{2} \operatorname{sex}$ & $\begin{array}{c}\text { Index of } \\
\text { expression }\end{array}$ & \\
\hline \multirow{8}{*}{$\mathrm{dm}^{2}$} & \multirow{4}{*}{ Tarahumara } & $0^{\pi}$ & R & 12 & 1 & 0 & 9 & 2 & 0 & n.s. & \multirow{4}{*}{ n.s. } & 1.55 & \multirow{4}{*}{1.47} \\
\hline & & & & & & & & & & \multirow{3}{*}{ n.s. } & & & \\
\hline & & $q$ & $\mathbf{R}$ & 12 & 4 & 2 & 6 & 0 & 0 & & & \multirow[t]{2}{*}{1.42} & \\
\hline & & & $\mathbf{L}$ & 10 & 2 & 1 & 7 & 0 & 0 & & & & \\
\hline & \multirow{4}{*}{ Mestizo } & $0^{7}$ & $\mathbf{R}$ & 9 & 1 & 0 & 7 & 1 & 0 & n.s. & \multirow{4}{*}{ n.s. } & 1.84 & \multirow{4}{*}{1.74} \\
\hline & & & $\mathbf{L}$ & 10 & 1 & 1 & 7 & 1 & 0 & & & & \\
\hline & & & & & & & & & & & & & \\
\hline & & 우 & $\begin{array}{l}\mathbf{R} \\
\mathbf{L}\end{array}$ & $\begin{array}{l}11 \\
12\end{array}$ & $\begin{array}{l}2 \\
1\end{array}$ & $\begin{array}{l}1 \\
1\end{array}$ & $\begin{array}{r}8 \\
10\end{array}$ & $\begin{array}{l}0 \\
0\end{array}$ & $\begin{array}{l}0 \\
0\end{array}$ & n.s. & & 1.65 & \\
\hline \multirow{8}{*}{$\mathrm{M}^{1}$} & \multirow{4}{*}{ Tarahumara } & $0^{n}$ & $\begin{array}{l}\mathbf{R} \\
\mathbf{L}\end{array}$ & $\begin{array}{l}31 \\
37\end{array}$ & $\begin{array}{r}12 \\
9\end{array}$ & $\begin{array}{l}14 \\
21\end{array}$ & $\begin{array}{l}4 \\
7\end{array}$ & $\begin{array}{l}1 \\
0\end{array}$ & $\begin{array}{l}0 \\
0\end{array}$ & n.s. & \multirow{4}{*}{ n.s. } & 0.88 & \multirow{4}{*}{0.94} \\
\hline & & & & & & & & & & \multirow{3}{*}{ n.s. } & & \multirow{3}{*}{1.00} & \\
\hline & & $q$ & $\mathbf{R}$ & 33 & 11 & 15 & 7 & 0 & 0 & & & & \\
\hline & & & $\mathbf{L}$ & 31 & 5 & 17 & 9 & 0 & 0 & & & & \\
\hline & \multirow{4}{*}{ Mestizo } & $\sigma^{*}$ & $\mathbf{R}$ & 16 & 5 & 7 & 4 & 0 & 0 & n.s. & \multirow{4}{*}{ n.s. } & 1.10 & \multirow{4}{*}{1.04} \\
\hline & & & $\mathbf{L}$ & 15 & 2 & 7 & 6 & 0 & 0 & & & & \\
\hline & & & & & & & & & & $n$ & & 089 & \\
\hline & & t & $\begin{array}{l}\mathbf{R} \\
\mathbf{L}\end{array}$ & $\begin{array}{l}42 \\
35\end{array}$ & $\begin{array}{l}14 \\
14\end{array}$ & $\begin{array}{l}20 \\
12\end{array}$ & $\begin{array}{l}7 \\
8\end{array}$ & $\begin{array}{l}1 \\
1\end{array}$ & $\begin{array}{l}0 \\
0\end{array}$ & n.s. & & 0.88 & \\
\hline \multirow{8}{*}{$\mathrm{M}^{2}$} & \multirow{4}{*}{ Tarahumara } & $\sigma^{\pi}$ & $\mathbf{R}$ & 23 & 13 & 6 & 4 & 0 & 0 & n.s. & \multirow{3}{*}{ n.s. } & 0.63 & \multirow{3}{*}{0.40} \\
\hline & & & & & & & & & & & & & \\
\hline & & q & $\mathrm{R}$ & 17 & 13 & 4 & 0 & 0 & 0 & n.s. & & 0.21 & \\
\hline & & & & & & & & & & & & & \\
\hline & & $d$ & $\mathbf{R}$ & 8 & 7 & 1 & 0 & 0 & 0 & n.s. & & 0.29 & \\
\hline & Mestizo & & $\mathbf{L}$ & 9 & 6 & 2 & 1 & 0 & 0 & & & & \\
\hline & Dinestizo & 우 & R & 20 & 13 & 6 & 1 & 0 & 0 & ns & n.s. & 0.33 & 0.32 \\
\hline & & & $\mathbf{L}$ & 16 & 12 & 4 & 0 & 0 & 0 & & & & \\
\hline
\end{tabular}

(except for mandibular M-D), making it the most diagnostic tooth for sexual differentiation.

Sexual dimorphism is shown for the second permanent molar tooth, with both Tarahumara and Mestizo females showing more recent cuspal patterns, and fewer cusps, than do the males. Statistically significant sexual dimorphism is also demonstrated for Carabelli's cusp for the second deciduous molar, first and second permanent molar. Greater sexual divergence is shown between Tarahumara and Mestizos. No sexual dimorphism was shown for the protostylid. In the protostylid no statistically significant differences were found between sexes or between left and right sides for each tooth group studied. How- ever, while both Mestizo and Tarahumara children showed a straight-line decrease in expression of the protostylid from the $\mathrm{dm}^{2}$ to $\mathrm{M}^{2}$, there were significant differences between these groups, with the Mestizo children having highest degree of expression for $\mathrm{dm}^{2}$ and $\mathrm{M}^{1}$ and the Tarahumara for $M^{2}$.

This study indicates that meaningful comparison of human populations can be made in terms of phenotypic frequencies of dental traits, even though both the protostylid and Carabelli's cusp appear to be polygenic traits. Of particular importance was the finding that when expressivity of traits such as Carabelli's cusp are examined based upon a trait analysis scale which includes the entire range of expres- 


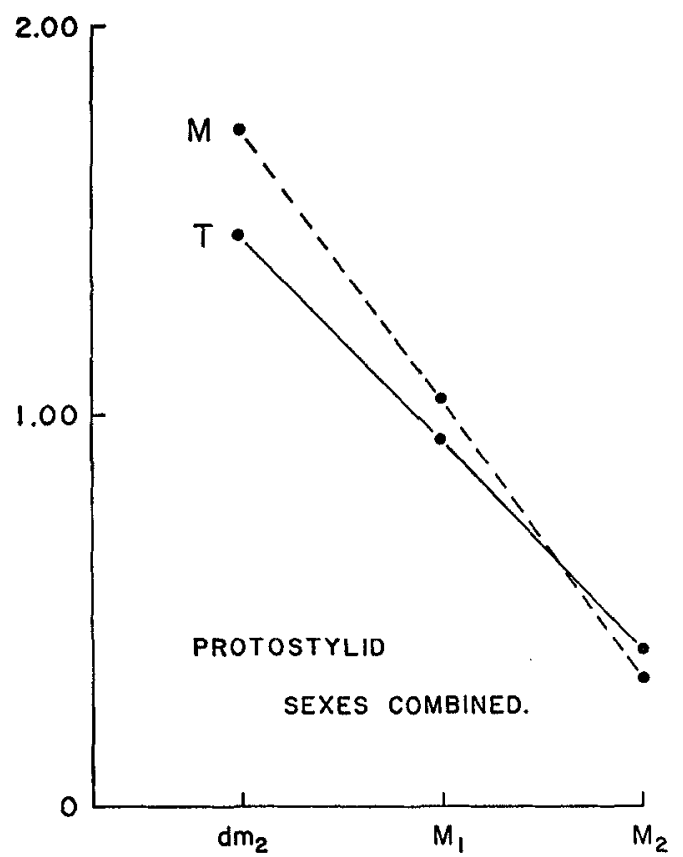

Fig. 8 Index showing relative degree of expression of the protostylid.

sions of the trait the frequency may be much higher than generally believed. Thus, while a low frequency of Carabelli's cusp has generally been regarded as a diagnostic racial trait for Mongoloid populations, on the contrary, this trait was found to range from $95 \%$ for Mestizo males to $100 \%$ for Tarahumara males in the population studies.

A rather surprising finding was the degree of discordance in Carabelli's cusp in the Mestizo female second deciduous and permanent molar, and in the Tarahumara female and male second deciduous molar. Even greater discordance was found in the protostylid, particularly in the Tarahumara male and female second deciduous molars, and the Mestizo female second deciduous molars. This technique of more discrete trait analysis should be applied to other populations, and currently work is underway to re-examine casts and skills of several previous American Indian dental collections.

\section{ACKNOWLEDGMENTS}

The authors are indebted to the priests, sisters and others of the Tarahumara Mission, and especially to the Reverends Luis Verplancken, S.J., Jose Llanguno, S.J., and Joseph Hernandez del C., S.J., for their generous assistance and hospitality. We also gratefully acknowledge the courteous response of the Tarahumara themselves, a people of patient dignity, who have much to teach their space-age contemporaries.

\section{LITERATURE CITED}

Ascher, R., and F. J. Clune 1960 Waterfall cove, southern Chihuahua. American Antiquity, 26: 270-274.

Balke, B., and C. Snow 1965 Anthropological and physiological observations on Tarahumara endurance runners. Am. J. Phys, Anthrop., 23(3): 293-302.

Bennett, W. C., and R. M. Zingg 1935 The Tarahumara. University of Chicago Press.

Dahlberg, A. A. 1949 The dentition of the American Indian. The physical anthropology of the American Indian. The Viking Fund, N. Y., pp. 138-176.

- 1959 Unpublished data.

Dietz, V. 1944 A common morphotrophic factor, the Carabelli cusp. J. Am. Dent. Assoc., 31: $784-789$.

Gajdusek, D. C. 1953 The Sierra Tarahumara. The Geographical Review, 43(1): 15-38.

Hrdlicka, A. 1908 Physiological and medical observations among the Indians of the southwestern United States and northern Mexico. Bureau of American Ethnology Bulletin 34, Smithsonian Institution, Washington, D. C.

- 1923 Variations in dimensions of lower molars in man and anthropoid apes. Am. J. Phys. Anthrop., 6: 423-438.

Jorgensen, K. D. 1956 The deciduous dentition: a description and comparative anatomical study. Acta Odont. Scand., 14(20).

Kraus, B. S. 1951 Carabelli's anomaly of the maxillary molar teeth: observations on Mexicans and Papago Indians and an interpretation of the inheritance. Am. J. Hum. Genetics, 3: 348-355.

1959 Occurrence of the Carabelli trait in southwest ethnic groups. Am. J. Phys. Anthrop., 17(2): 117-123.

Pennington, C. W. 1963 The Tarahumara of Mexico. University of Utah, Salt Lake City.

von Carabelli, G. 1842 Systematisches Handbuch der Zahnheilkunde, Band \#. Braumüller and Seidel, Wien.

Zingg, R. M. 1940 Report on the archaeology of southern Chihuahua. III. Contributions, University of Denver.

1942 The genuine and spurious values in Tarahumara culture. Am. Anthrop., 44: 7892. 